\title{
Greetings from the new Editor-in-Chief
}

\author{
Kouki Hikosaka ${ }^{1}$
}

Published online: 7 April 2017

(C) The Botanical Society of Japan and Springer Japan 2017

It is an honor to take over the position of Editor-in-Chief of the Journal of Plant Research (JPR), starting my 4-year mission from 5 March 2017, following the former Editorin-Chief, Professor Ikuo Nishida of Saitama University. I wish to do my best to improve the quality and impact of $J P R$.

This year is the 130th anniversary of the foundation of Shokubutsugaku Zasshi (a botanical magazine in Japanese), the predecessor of JPR. It is surprising that it was founded only 11 years after the end of Japan's period of isolation. Although Shokubutsugaku Zasshi published only papers written in Japanese in its early years, these include the invaluable finding on the sperm of Ginkgo biloba L. (Hirase 1896) and Cycas revoluta Thunb. (Ikeno 1896). The first paper written in English was published in 1890 (Miyoshi 1890), which might be the beginning of the internationalization of the journal. From the second English paper (Yatabe 1890), the Shokubutsugaku Zasshi had the English name The Botanical Magazine (The Botanical Magazine, Tokyo). Thereafter, The Botanical Magazine published papers written not only in Japanese but also in English or German. The editorial committee of The Botanical Magazine decided to publish all articles in English in 1972 (Nishitani 2007). The name of the journal was changed to the Journal of Plant Research in 1993, and online publication of JPR started in 2003.

$J P R$ has become a truly international journal. In 2016, $89 \%$ of submitted papers were from outside of Japan (Fig. 1). Remarkable changes can be seen in recent decades.

Kouki Hikosaka

hikosaka@m.tohoku.ac.jp

1 Graduate School of Life Sciences, Tohoku University, Aoba, Sendai 980-8578, Japan
Whereas the number of submitted papers from Japan had been greater until 2004, submissions from abroad drastically increased after the start of online submissions and continue to increase. It is regrettable that we have to reject many papers due to a limitation of pages.

$J P R$ has provided opportunities for publishing across the breadth of plant sciences: taxonomy, phylogenetics, and evolutionary biology; ecological, ecophysiological, and environmental biology; morphology, anatomy, and structural biology; genetics and developmental biology; physiology, biochemistry, and molecular and cell biology; and other related fields (Nishida 2017). This policy seems an opposite direction to the current trend, where scientific interests tend to be deepened and divided into narrow areas. However, recent advances in molecular biological techniques enable fusion of different areas in biology. For example, evolutionary biology previously dealt with genes only as neutral markers, whereas current evolutionary biologists are also interested in the evolution of functional genes. Many ecologists study the role of functional genes in adaptation to specific environments. Numbers of developmental biologists and others are interested in differences in molecular mechanisms between algae, mosses, and seed plants. The JPR Symposium published in this issue, "Fusion in Fertilization: Interdisciplinary Collaboration Among Plant and Animal Scientists", is quite challenging for interdisciplinary "fusion" (Yamato and Kuchitsu 2017). The symposium consists of papers on fusion in algae, plants, and animals (Alvarez 2017; Inoue 2017; Kinoshita et al. 2017; Kurusu and Kuchitsu 2017; Minamino et al. 2017; Miyado et al. 2017; Okamoto et al. 2017; Sekimoto et al. 2017; Shiba and Inaba 2017). I am very pleased to publish this issue and to see that JPR provides opportunities for such interdisciplinary research. 


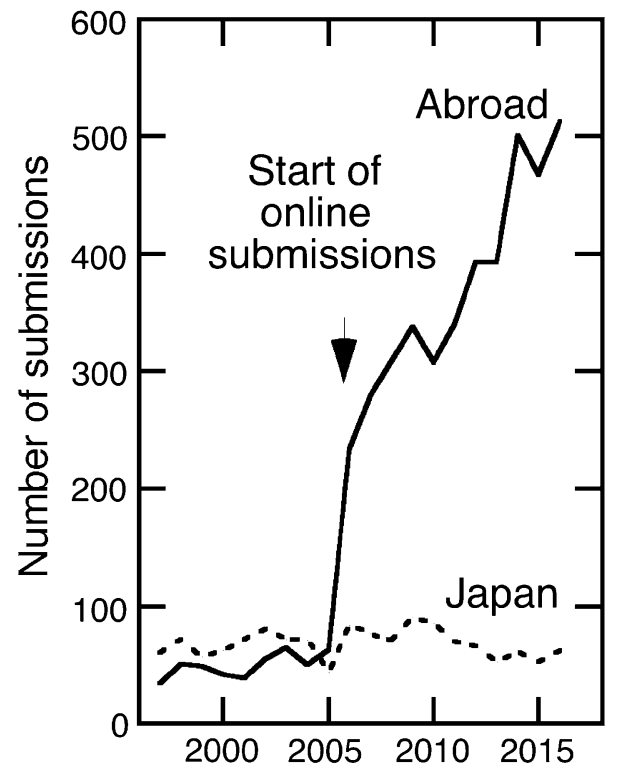

Fig. 1 Number of submissions to the Journal of Plant Research from Japan and abroad

As introduced by Prof. Nishida (2017), we have inaugurated a new editorial team beginning in 2017. I would like to express my appreciation for the Editors-Drs. Atsushi Ebihara, Hajime Ikeda, Eric DeChaine, Rhett D. Harrison, Hiroyuki Muraoka, Shuichi Sakaguchi, Ichiro Karahara, Tomoaki Nishiyama, Thomas Berberich, Tomoaki Fujita, Hajime Wada, Naoto Kawakami, and Kintake Sonoikewho will handle a large quantity of papers. I also thank the Editorial Board members, who will help to improve the quality of $J P R$. It is our great pleasure, as well, to have a new secretary of $J P R$, Dr. Masako Mishio. Together with constant support from all the Editors, Editorial Board members, and Advisory Board members, I am sure that through its publication, JPR will continue to provide the public with the fruits of our labors in plant sciences.

\section{References}

Alvarez L (2017) The tailored sperm cell. J Plant Res. doi:10.1007/ s10265-017-0936-2

Hirase S (1896) Ichou-no-seishi-ni-tsuite (in Japanese) (On the spermatozoid of Ginkgo biloba). Shokubutsugaku-Zasshi (Bot Mag) 10:325-328

Ikeno S (1896) Sotetsu-no-seichu (in Japanese) (Spermatozoid of Cycas revoluta). Shokubutsugaku-Zasshi (Bot Mag) 10:367-377

Inoue N (2017) Novel insights into the molecular mechanism of sperm-egg fusion via IZUMO1. J Plant Res. doi:10.1007/ s10265-016-0895-z

Kinoshita N, Nagasato C, Motomura T (2017) Phototaxis and chemotaxis of brown algal swarmers. J Plant Res. doi:10.1007/ s10265-017-0914-8

Kurusu T, Kuchitsu K (2017) Autophagy, programmed cell death and reactive oxygen species in sexuyal reproduction in plants. J Plant Res. doi:10.1007/s10265-017-0934-4

Minamino N, Kanazawa T, Nishihama R, Yamato KT, Ishizaki K, Kohchi T, Nakano A, Ueda T (2017) Dynamic reorganization of the endomembrane system during spermatogenesis in Marchantia polymorpha. J Plant Res. doi:10.1007/s10265-017-0909-5

Miyado K, Kang W, Yamatoya K, Hanai M, Nakamura A, Mori T, Miyado M, Kawano N (2017) Exosomes versus microexosomes: shared components but distinct functions. J Plant Res. doi:10.1007/s10265-017-0907-7

Miyoshi M (1890) Notes on Pinguicula ramosa, sp. nov. Shokubutsugaku Zasshi 4:315-316

Nishida I (2017) With gratitude for the Journal of Plant Research. J Plant Res 130:1-2

Nishitani K (2007) From the editor-in-chief: toward a new era for the Journal of Plant Research. J Plant Res 120:1-2

Okamoto T, Ohnishi Y, Toda E (2017) Development of polyspermic zygote and possible contribution of polyspermy to polyploid formation in angiosperms. J Plant Res. doi:10.1007/ s10265-017-0913-9

Sekimoto H (2017) Sexual reproduction and sex determination in green algae. J Plant Res. doi:10.1007/s10265-017-0908-6

Shiba K, Inaba K (2017) Inverse relationship of $\mathrm{Ca}^{2+}$-dependent flagellar response between animal sperm and prasinophyte algae. J Plant Res. doi:10.1007/s10265-017-0931-7

Yamato K, Kuchitsu K (2017) "Fusion" in fertilization: interdisciplinary collaboration among Plant and Animal Scientists. J Plant Res. doi:10.1007/s10265-017-0937-1

Yatabe R (1890) A new genus of the order Saxifragaceae 4:433-435 